\title{
THE IMPORTANCE OF DATA: DEVELOPING SMART ASSET MANAGEMENT FRAMEWORK IN IOT ERA
}

\author{
Marga Gumelar \\ marga16001@mail.unpad.ac.id \\ Faculty of Economics and Business \\ Universitas Padjadjaran Bandung, \\ 40132, Indonesia
}

\begin{abstract}
Municipal assets become hard problems that lasted a long time. In the fiscal year 2015, from total asset amount of $\mathrm{Rp} 2,048.88$ trillion, the Audit Board of the Republic of Indonesia found some problems on the audit of the local government financial report that 1,010 issues were related to asset registration. There were also 48 problems related to unknown assets and potential losses of Rp 289,281.23 million. This paper aims to develop municipal asset management framework by focusing on asset inventory system through the application of information technology. A case study is presented based on the findings of the Audit Board of the Republic of Indonesia. The result is a practical asset inventory system framework to improve current asset inventory performance. The use of information technology can support the improvement of municipal asset management. But the tools are not enough without collaboration with employees. Since some regions in Indonesia inadequately have information technology infrastructure facilities, such as internet access and electricity network, this framework has obvious limitation.
\end{abstract}

Keywords-asset inventory; sustainable asset management; municipal asset; data management; IoT

\section{A. INTRODUCTION}

This paper aims to develop municipal asset management framework by focusing on asset inventory system through the application of information technology. It uses a case study based on the findings of the Audit Board of the Republic of Indonesia. Its result is supposed to contribute to the improvement of asset inventory performance. It is hoped that asset inventory problems will not occur in the future.

Asset management is a set of processes related to decision-making based on mastering of the physical condition and performance of assets [1]. Definition of 
asset management according to the standard of ISO 55000 [2] is an integrated action, combining the used systems, the planning, and the application, in an organization to comprehend the value of an asset. In another concept [3], asset management is a process of organizing, planning, designing and controlling the acquisition, maintenance, improvement, and asset selling and engineering infrastructure to support service delivery. It is also defined as a strategy of continuous improvement process to improve the availability, protection, reliability, and life cycle of assets [4].

Municipal asset management [5] is a process of creating decisions and implementing them regarding operating, maintaining, refurbishing, acquiring, or developing physical assets cost-effectively, with the ultimate objectives of providing the best possible service to local citizens. It explains that asset management has a capacity to get a straight achievement on the lives of local citizens. There are three important things in the municipal asset management [6] include asset life cycle, the capacity of each asset, and assets information system.

The value of asset management system [4] is to notice us about our own assets including the description, position, condition, and use; and to arrange maintenance program to make sure that each asset performs reliably. It is systematic, structured and it covers the whole life of physical assets. The meaning of asset management is to optimize the potential of the assets and to minimize the risks and costs [3]. To support economic development, local governments must manage their asset correctly. When the assets are not well managed, their quality and quantity would not be useful. The ability of a budget cost is influenced by cost efficiency of employing assets, facilities, and infrastructure [7].

Municipal assets become hard problems that lasted a long time. One problem forwarded by The Audit Board of The Republic of Indonesia, wellknown as BPK, that occurred in local government asset management was the deficiency of the system for asset inventory [8] [9] [10] [11]. The term "asset" here refers to fixed asset. The fixed asset is one of the strategic assets owned by the government. It also has, in general, a value most large compared to other accounts in the financial statements. 
In the fiscal year 2015, the audit of local government financial report found that 1,010 issues were related to asset registration. These findings were related to internal controls. There were also 48 problems related to unknown assets and potential losses of $\operatorname{Rp} 289,281.23$ million [10] [11].

The asset inventory issues have always been the finding of BPK occurring over the years without any completion. Therefore there is a need of deepening to the problems that actually happened to take a workable solution to fix it.

Asset inventory is a registration activity that plays a critical role in the asset management and should be strengthened up with a good system to generate a database that has been the basic foundation for making the right decision [5] [6] [14].

Asset inventory according to the Government Regulation No.27/2014 is a series of actions in the form of collecting data, recording, and reporting of all state/municipal property [13].

Many public entities do not have a good asset inventory that allows them to understand the total value of their assets. It is difficult to monitor and control the use of public assets, particularly when the inventory of public assets is quite large. The uses of public assets without prior assessment and without examining the needs of the community are negative impacts of incomplete and inaccurate of public asset inventory. Asset inventory is also related to government accountability and the terms of accounting [12].

Data is a decisive subject on asset management. Every activity such as planning, strategy development, and assessment, based on a good quality of data. The decision making of asset managers established on this information consists of the location, condition, specification, maintenance cost, and use of assets [2] [15]. Data in asset inventory is the main pillar in the asset life cycle for local government. It will also tell us about the maintenance schedule as well as public safety actions are taken in case of failure incident [6].

Data management on asset inventory depends on the amount of asset [15]. Data should be updated, accurate, completed and consistent so it will support the good data management. It should be accessible and exposed at any time in the 
right format. Poor data can be misleading in decision making. It also means no data. Data management can be done through the planning of system and process in effective asset recording as well as consolidation, updating, and reporting process. All of these processes cannot be achieved easily and it takes time.

The paper is structured as follows. It begins with an introduction to the study. The second section discusses the need for good data management. The third section explains the current issues in asset inventory and the audit findings of BPK. The fourth section is talking about the collaboration between tools and people to improve asset inventory system. Finally, it closes with the conclusion of the paper.

\section{B. METHODS}

This paper uses a case study based on the findings of the BPK's audit. BPK did two kinds of audit related to municipal asset management in 2016. The first was the audit of the local government financial report and done for all local government in Indonesia. The second was the audit for the special purpose of asset management and done for 23 entities of local government.

In the fiscal year 2015, all local governments in Indonesia have assets worth Rp 2,048.88 trillion. More than 10 percent of the assets' value was problematic with respect to asset inventory. The audit of local government financial report found that 1,010 issues were related to asset registration. These findings were connected to internal controls. There were 48 problems related to unknown assets and potential losses of $\operatorname{Rp} 289,281.23$ million [10] [11].

While in the audit with a specific purpose on the asset management of 23 entities, there were 92 problems associated with asset registration. In addition, there were 9 issues related to unknown assets and potential losses of $\mathrm{Rp}$ $616,726.80$ million [10] [11].

The cases based on BPK`s findings [10] [11] are summarized in Table 1.

TABLE I. BPK'S AUDIT FINDINGS SUMMARY

\begin{tabular}{|l|l|l|}
\hline No. & Audit Findings and Entity & Note \\
\hline
\end{tabular}




\begin{tabular}{|c|c|c|}
\hline No. & Audit Findings and Entity & Note \\
\hline 1. & $\begin{array}{l}\text { Acquisition prices or fair prices were not } \\
\text { used as the basis for fixed assets recording in } \\
\text { the Municipal Government of South } \\
\text { Minahasa. }\end{array}$ & - \\
\hline 2. & $\begin{array}{l}\text { Fixed assets details such as wide detail, full } \\
\text { address/location, and land code number were } \\
\text { not included in the listing in the City } \\
\text { Government of Pekanbaru. }\end{array}$ & - \\
\hline 3. & $\begin{array}{l}\text { Fixed assets in the form of buildings and } \\
\text { constructions already auctioned and/or } \\
\text { removed a total of } 71 \text { units were still listed } \\
\text { in the municipal asset register in the } \\
\text { Municipal Government of West Tanjung } \\
\text { Jabung. }\end{array}$ & - \\
\hline 4. & $\begin{array}{l}\text { There has been no recording of fixed assets } \\
\text { in the form of land under the road space, } \\
\text { land under drainage and irrigation areas, and } \\
23 \text { plots of land in the City Government of } \\
\text { Semarang. }\end{array}$ & - \\
\hline 5. & $\begin{array}{l}\text { Not all of fixed assets in the form of roads } \\
\text { and irrigation shall be capitalized and } \\
\text { recorded with detailed detail covering } \\
\text { location/location, length, and width of road } \\
\text { and irrigation in the Municipal Government } \\
\text { of North Bolaang Mongondow. }\end{array}$ & - \\
\hline 6. & $\begin{array}{l}\text { The assets of social and public facilities in } \\
\text { the form of } 2 \text { parcels of land that should be } \\
\text { handover by the developer were not found in } \\
\text { the provincial government of DKI Jakarta. }\end{array}$ & $\begin{array}{l}\text { Potential loss of } \\
\operatorname{Rp} 371.23 \\
\text { billion. }\end{array}$ \\
\hline 7. & $\begin{array}{l}\text { There were a number of assets untracked the } \\
\text { existence in } 23 \text { working units in the form of } \\
\text { land, building, and construction; equipment } \\
\text { and machinery; roads and irrigation; and } \\
\text { other assets in the Municipal Government of } \\
\text { Paniai. }\end{array}$ & $\begin{array}{l}\text { Potential loss of } \\
\operatorname{Rp} 161.16 \\
\text { billion. }\end{array}$ \\
\hline 8. & $\begin{array}{l}\text { A number of fixed assets were not known to } \\
\text { exist in the form of vehicles, agricultural } \\
\text { equipment, and water transportation in the } \\
\text { Municipal Government of Muna. }\end{array}$ & $\begin{array}{l}\text { Potential loss of } \\
\text { Rp } 44.50 \text { billion. }\end{array}$ \\
\hline 9. & $\begin{array}{l}\text { A number of fixed assets were not known to } \\
\text { exist in the form of machinery; road and } \\
\text { irrigation; and other assets in the Municipal } \\
\text { Government of South Minahasa. }\end{array}$ & $\begin{array}{l}\text { Potential loss of } \\
\text { Rp } 27.37 \text { billion. }\end{array}$ \\
\hline 10 & $\begin{array}{l}\text { The assets of } 35 \text { vehicles were not known to } \\
\text { exist in the Municipal Government of Teluk }\end{array}$ & $\begin{array}{l}\text { Potential loss of } \\
\text { Rp } 7.93 \text { billion. }\end{array}$ \\
\hline
\end{tabular}




\begin{tabular}{|l|l|c|}
\hline No. & \multicolumn{1}{|c|}{ Audit Findings and Entity } & Note \\
\hline & Wondama. & \\
\hline
\end{tabular}

\section{RESULT AND DISCUSSION}

This section discusses the framework of asset inventory system through the application of information technology implementation of information based on cases above. Use of information technology is necessary to facilitate the registration process and get accurate results. Since some regions in Indonesia inadequately have information technology infrastructure facilities, such as internet access and electricity network, the framework has obvious limitation. In addition, the competence of human resources and the pattern of employee mutations that often occur in the local government becomes another obstacle in the implementation of this framework.

A well-functioned inventory system is a requirement to support the success of municipal asset management. It should accommodate a complete and valid information that can quickly determine what the local governments have and the type of asset and location are, as well as updating the value. Asset managers have to look at whether the asset inventory has been reliable so that it can be used as a database. The accuracy of such information is appropriate to be considered for statements of assets. Improvements in asset inventory management are concluded through a constant process by updating regularly [14].

In recent years, there has been a trend for local governments to transform from conventional city to smart city. The concept of the smart city using information technology in delivering public services also reaches on the local government asset management. Although it is not yet fundamentally done, some local governments have used online and offline systems in asset management.

The application can simply be classified into two categories. The first is the Regional Management Information System of Local Property that is called SIMDA BMD. SIMDA BMD is an application developed by the Financial and Development Supervisory Board (BPKP) that is distributed free of charge to local 
governments. This application was claimed to be used by 347 local governments in 2016 [16]. Unfortunately, SIMDA BMD is an offline application. The second is the Regional Goods Management Information System, named with SIMBADA, which is a paid online application and developed by the private provider.

Use of the application in local government asset management though helpful but still cannot solve the asset problems. Until last year, BPK's findings still highlighted the issues of fixed asset to local governments. Asset inventory issues were one of the major issues. Manual recording of assets still often made the data inaccurate. Moreover, there was no control over asset movements. So repeatedly the asset was not known to exist even though it was recorded on the system.

The implementation of data collecting on assets such as land, building, machinery, vehicle, and equipment, needs the detail information. It includes such as ownership status; location; current use; structural type; size; age; previous use; value; maintenance history; and other issues like legal action [6].

The needs of users and stakeholders should be considered in the data management system. They are: 1) to inform asset review, appraisal, planning, and decision-making; 2) to monitor and evaluate the implementation of assets strategy and asset performance; 3) to comply with legislation and reporting on external parties; 4) to support sustainable asset management; 5) to maintain a complete and accurate asset inventory [15].

This paper develops a conceptual framework using information technology tools in order to create a reliable asset inventory system.

A. The Use of Tools in Creating a Reliable Asset Inventory System

This framework uses simple tools that are easy to buy in the market. The tools are:

\section{Server}

Local governments must have adequate servers to run all applications used in delivering services to the public and also in storing government 
data. The server must standby 24 hours and has a generator that automatically turns on when the power goes out.

. Online and Mobile Application

Online and mobile applications are required to facilitate asset inventory and monitor asset status. Applications that can be accessed through apps on smartphones can help asset register directly connected to the system.

There are two types of applications that have been used by local governments, namely SIMDA BMD an offline based application and SIMBADA an online based application. Both of these applications have adequate asset inventory feature.

An online application that has mobile features on a smartphone is the right choice to support a reliable asset inventory system.

1 PC/Smartphone/Tablet

The use of mobile devices such as smartphones and tablets is very useful in updating asset information when visiting the field. The data obtained becomes more accurate.

\section{. Barcode and Mobile Scanner}

Barcodes used so far are useless. Supposed to use barcode will facilitate asset registration and asset monitoring just by doing a scan of the barcode. Asset mobility such as cameras, printers, and other electronic devices can be easily tracked because asset lending should be with barcode scans. So hopefully BPK findings for assets that are not known to exist will not happen again in the future.

\section{Global Positioning System (GPS)}

GPS is used on vehicles includes car or motorcycle. This tool works like a barcode that can track the presence of a vehicle. 


\section{B. People: Competency and The Employee Mutation}

To build a reliable asset inventory framework, it is not enough fulfilled from the completeness of information technology infrastructure. There needs to be collaboration from employees. The competence of local government employees who become operators of asset information systems should be advanced. Continuous training and knowledge transfer from application provider are required. Increased competence can also be held internally through discussions or knowledge-cafe.

This human resource problem is in accordance with the findings of other researchers [12] [17]. Incompetence was one of the problems [12]. The staffs of local government were not capable and less skillful to run the asset management. There were also not sufficient continuous training programs [17].

Another thing related to employees is the pattern of employee mutations in the local government environment that is unpredictable. Whereas information system operators and asset holders play an important role in the management of regional assets. Often when employees have mastered the field of assets through training and increased competence that takes time and cost, suddenly there is a mutation of employees. As a result, the work unit must retrain new employees so that the asset management becomes in-optimal.

\section{CONCLUSION}

The problem of assets dwellings on asset inventory. For that, we need a simple new framework that can be implemented in improving the asset inventory system. The use of information technology can support the improvement. But the tools are not enough without collaboration with employees. Employees' competence must be advanced first. However, when the competence is successfully upgraded, other problems related to employees are the pattern of local government mutations. Often the employees responsible for asset management are suddenly transferred. This tendency causes local government asset management to be less optimal 


\section{E. REFERENCES}

[1] Worley International Ltd, "Strategic municipal asset management," World Bank, Municipal Background Series No.5, April 2000.

[2] The Institute of Asset Management, "Asset management - an anatomy," Version 3, December 2015.

[3] The Australian Asset Management Collaborating Group, "Guide to integrated strategic asset management," Brisbane: The Australian Asset Management Collaborative Group, 2012.

[4] J. Davis, "What is asset management and where do you start?," American Water Works Association, Journal, 99(10), 2007, pp. 26.

[5] O. Kaganova and M. Kopanyi, "Managing local assets," In C. Farvacque-Vitkovic, and M. Kopanyi, Eds. Municipal finances, a handbook for local governments, Washington, DC: The World Bank, 2014, pp. 275-324.

[6] The Auditor General for Local Government, "Asset management for local governments," AGLG Perspective Booklet, Audit Topic 3, July 2015.

[7] O. Kaganova, "Managing government capital assets in the state of California: what can be learned from other governments?," Testimony for Little Hoover Commission, January 2012.

[8] The Audit Board of The Republic of Indonesia [Badan Pemeriksa Keuangan], "The first-semester report of 2015" [Ikhtisar hasil pemeriksaan semester I tahun 2015], Indonesia, Jakarta: BPK, 2015.

[9] The Audit Board of The Republic of Indonesia [Badan Pemeriksa Keuangan], “The second-semester report of 2015" [Ikhtisar hasil pemeriksaan semester II tahun 2015], Indonesia, Jakarta: BPK, 2016.

[10] The Audit Board of The Republic of Indonesia [Badan Pemeriksa Keuangan], "The first-semester report of 2016" [Ikhtisar hasil pemeriksaan semester I tahun 2016], Indonesia, Jakarta: BPK, $2016 \mathrm{a}$. 
[11] The Audit Board of The Republic of Indonesia [Badan Pemeriksa Keuangan], "The second-semester report of 2016" [Ikhtisar hasil pemeriksaan semester II tahun 2016], Indonesia, Jakarta: BPK, 2017.

[12] M. Grubišić, M. Nušinović, and G. Roje, "Towards efficient public sector asset management," Financial theory and practice, 33(3), 2009, pp. 329-362.

[13] The Government of the Republic of Indonesia, Government Regulation No.27/2014 on State/Municipal Asset Management.

[14] F. Fernholz and R. M. Fernholz, "A toolkit for municipal asset management," Duke University, March 2007.

[15] K. Jones and A. D. White, "RICS public sector asset management guidelines," RICS, London, 2008.

[16] Financial and Development Supervision Board [Badan Pengawasan Keuangan dan Pembangunan], "Introduction to Sistem Informasi Manajemen Daerah (SIMDA)" [Pengenalan Sistem Informasi Manajemen Daerah (SIMDA)], Retrieved June 20, 2017, from http://www.bpkp.go.id/sakd/konten/333/Versi-2.1.bpk

[17] R. Simamora and A. Halim, "Factors affecting asset management postredistricting and its effect on quality of government financial statements in South Tapanuli“" [Faktor-faktor yang mempengaruhi pengelolaan aset pasca pemekaran wilayah dan pengaruhnya terhadap kualitas laporan keuangan pemerintah di Kabupaten Tapanuli Selatan], Jurnal Ekonomi dan Bisnis, 2012, 10(1). 47-61. 